\title{
TINGKAT MOTIVASI PETANI DAN KUALITAS PELAYANAN PENYULUHAN PERTANIAN di KAWASAN PERBATASAN (STUDI KASUS di KECAMATAN KRAYAN KABUPATEN NUNUKAN)
}

\section{THE LEVEL FARMER MOTIVATION AND SERVICES QUALITY OF AGRICULTURAL EXTENSION IN BORDER AREAS (CASE STUDY IN KECAMATAN KRAYAN KABUPATEN NUNUKAN)}

\author{
Sekar Inten Mulyani ${ }^{1)}$, Anang Sulistyo ${ }^{2)}$, Rayhana Jafar ${ }^{3)}$ \\ 1,2,3) Program Studi Agribisnis Fakultas Pertanian Universitas Borneo Tarakan \\ Jalan Amal Lama Nomor 1, Tarakan \\ Email: ${ }^{1}$ inten131313@gmail.com
}

\begin{abstract}
ABSTRAK
Krayan merupakan salahsatu Kecamatan yang ada di Kabupaten Nunukan yang berbatasan langsung dengan Malaysia. Sebagian besar penduduknya bermata pencaharian petani, sehingga perlu mengoptimalkan kegiatan penyuluhan pertanian agar dapat meningkatkan pengetahuan,sikap dan keterampilan petani dalam berusahatani. Tujuan penelitian ini adalah :1) Mengetahui tingkat motivasi petani mengikuti penyuluhan pertanian di Kecamatan Krayan ;2) Mengetahui kualitas Pelayanan penyuluhan pertanian di Kecamatan Krayan dan 3) Menganalisis hubungan antara motivasi petani dan kualitas pelayanan penyuluhan di Kecamatan Krayan. Penelitian ini dilaksanakan di Kecamatan Krayan Kabupaten Nunukan pada Bulan Agustus sampai dengan November 2018. Tujuan pertama dan kedua dianalisis menggunakan metode deskritif kuantitatif yaitu menggunakan bantuan kuesioner kemudian data diolah dengan metode skoring berdasarkan skala likert dan dari hasil tabulasi data akan dideskripsikan mengenai tingkat motivasi petani dan kualitas pelayanan penyuluhan pertanian di Kecamatan Krayan.Tujuan ketiga menggunakan analisis korelasi Spearman Rank $(\rho)$ dengan bantuan SPSS untuk menganalisis hubungan antara motivasi petani dan kualitas pelayanan penyuluhan di Kecamatan Krayan. Responden yang diambil sebanyak 40 petani dengan metode quota sampling. Tingkat motivasi dengan indikator motivasi intrinsik dan ekstrinsik. Tingkat kualitas pelayanan penyuluhan dilihat dari lima dimensi yaitu aspek fisik (tangible), kehandalan (reliability), daya tanggap (responsiviness), jaminan (assurance) dan empati (emphaty). Hasil penelitian menunjukkan tingkat motivasi petani $60 \%$ dalam kategori tinggi dan $40 \%$ sangat tinggi. Persepsi petani mengenai tingkat kualitas pelayanan penyuluhan adalah $5 \%$ menyatakan cukup, $42,5 \%$ baik dan $52,5 \%$ sangata baik. Hubungan antara tingkat motivasi dan tingkat kualitas pelayanan penyuluhan sebesar 0,566 (korelasi sedang) dengan signifikansi 0,000 (signifikan).
\end{abstract}

\section{Kata Kunci : Kualitas Pelayanan, Motivasi, Petani, Penyuluhan Pertanian}

\begin{abstract}
Krayan is one of the Districts in Nunukan Regency which borders Malaysia directly. Most of the population are farmers, so they need to optimize agricultural extension activities so that they can improve the knowledge, attitudes and skills of farmers in farming. The objectives of this study were: 1) To find out the motivation level of farmers following agricultural counseling in Krayan Subdistrict; 2) Know the quality of agricultural extension services in Krayan District and 3) Analyze the relationship between farmer motivation and quality of extension services in Krayan District. This research was conducted in Krayan District, Nunukan Regency in August to November 2018. The first and second objectives were analyzed using quantitative descriptive method, namely using questionnaire assistance, then the data was processed by scoring method based on the Likert scale and from the tabulation data will be described about farmers' motivation level and quality of agricultural extension services in Krayan District. The third objective uses Spearman Rank correlation analysis $(\rho)$ with the help of SPSS to analyze the relationship between farmer motivation and the quality of extension services in Krayan District. Respondents were taken as many as 40 farmers with the quota sampling method. The level of motivation with indicators of intrinsic and extrinsic motivation. The level of quality of extension services is seen from five dimensions, namely tangible, reliability, responsiveness,
\end{abstract}


assurance and empathy. The results showed that the motivation level of farmers was $60 \%$ in the high category and $40 \%$ was very high. Farmers' perceptions about the level of quality of extension services were $5 \%$ which stated that they were sufficient, $42.5 \%$ were good and $52.5 \%$ were good. The relationship between motivation level and extension service quality level is 0.566 (moderate correlation) with a significance of 0.000 (significant).

\section{Keywords: Service Quality, Motivation, Farmers, Agricultural Extension}

\section{PENDAHULUAN}

Penyuluhan pertanian merupakan salah satu pendidikan informal yang diberikan petani melalui petugas penyuluh yang berasal dari Dinas Pertanian setempat. Peningkatan perilaku petani tak lepas dari peran dari penyuluh. Perilaku petani ini meliputi pengetahuan, sikap dan keterampilan petani dalam berusaha tani. Penyuluh sebagai ujung tombak yang langsung menyampaikan informasi, kebijakan pemerintah maupun inovasi terbaru untuk petani. Dalam pelaksanaan penyuluhan membutuhkan adanya partisipasi aktif dari petani, karena paradigma penyuluhan sekarang adalah penyuluhan partisipatif. Menghadapi era agribisnis dan otonomi daerah, diperlukan adanya paradigma penyuluhan pertanian yang memposisikan petani dan keluarganya sebagai fokus kegiatan pembangunan pertanian. Oleh karena itu kegiatan penyuluhan pertanian harusnya lebih diarahkan kepada upaya pemberdayaan petani dan keluarganya agar mampu menerapkan konsep agribisnis secara utuh dan selaras dengan potensi wilayah serta memperhatikan kelestariannya (Abubakar, 2010) Kecamatan Krayan merupakan salah satu kecamatan yang berada di Kabupaten Nunukan. letaknya sangat strategis karena daerahnya berbatasan langsung dengan Malaysia melalui jalan darat. Sebagian besar penduduk Krayan bermatapencaharian sebagai petani,sehingga perlu mengoptimalkan kegiatan penyuluhan pertanian agar dapat meningkatkan produktivitas hasil-hasil pertaniannya sehingga dapat mewujudkan kesejahteraan petani di daerah perbatasan.

Secara umum petani di Kecamatan Krayan memiliki motivasi mengikuti penyuluhan apabila ada kegiatan yang bersifat temporer dan motivasi yang ada belum dikarenakan adanya kebutuhan dan kemauan secara langsung yang berasal dari petani itu sendiri. Hal ini terlihat dari masih sedikitnya jumlah petani yang secara rutin mengikuti penyuluhan pertanian Motivasi diasumsikan sebagai individu untuk mencapai tujuan secara kognitif, sedangkan dalam arti afeksi, motivasi bermakna sikap dan nilai dasar yang dianut oleh seseorang atau sekelompok orang untuk bertindak atau tidak bertindak, dapat disimpulkan motivasi adalah sebagai kekuatan, dorongan. Motivasi petani untuk bergabung dalam kelompok tani sebagai pengelola usahatani diartikan sebagai kondisi yang mendorong untuk melakukan tindakan mengikuti penyuluhan dengan tujuan tertentu (Hidayanti, 2015).

Motivasi petani mengikuti penyuluhan tidak terlepas dari kualitas pelayanan penyuluhan yang diberikan oleh penyuluh ketika memberikan penyuluhan pertanian. Kualitas penyuluhan dapat dilihat dari beberapa aspek yaitu aspek tangible (kualitas fisik), reliability (keandalan), responsiveness (daya tanggap), insurance (jaminan) dan Empathy (empati).

Tujuan dari penelitian ini adalah untuk mengetahui tingkat motivasi petani mengikuti penyuluhan pertanian, mengetahui kualitas Pelayanan penyuluhan pertanian, dan hubungan antara motivasi petani dan kualitas pelayanan penyuluhan di Kecamatan Krayan. Oleh karena itu dilakukan penelitian untuk melihat hubungan antara motivasi petani dan kualitas pelayanan penyuluhan pertanian di Kecamatan Krayan agar tercapai kesejahteraan petani di kawasan perbatasan.

\section{METODE PENELITIAN}

Penelitian ini dilaksanakan di Kecamatan Krayan Kabupaten Nunukan. Kecamatan Krayan merupakan salah satu wilayah yang berbatasan langsung dengan Malaysia. Penelitian ini akan 
dilaksanakan pada Bulan Agustus sampai dengan Bulan November 2018.

Metode yang digunakan dalam penelitian adalah metode survai. Data yang diambil berupa data primer dan data sekunder. Data primer diperoleh melalui wawancara dengan berpedoman pada kuesioner yang telah dipersiapkan sebelumnya dan pengamatan langsung atau observasi lapangan pada petani terpilih (Arikunto, 2008). Data primer yang dikumpulkan, terutama tentang karakteristik petani (umur, pengalaman berusaha tani, tingkat pendidikan, status sosial, frekuensi penyuluhan,motivasi petani,dan persepsi mengenai kualitas pelayananan penyuluhan ). Data sekunder merupakan data pendukung dan pelengkap yang didapat dari lembaga atau instansi yang berkaitan dengan penelitian ini.

Metode Sampel menggunakan metode quota sampling. Kriteria responden yang diambil adalah : 1) Petani di Kecamatan Krayan ; 2) Tergabung atau menjadi anggota kelompok tani ; 3) Aktif mengikuti pertemuan kelompok tani, responden yang diambil adalah sebanyak 40 petani yang diambil dari Gapoktan Rimba Lestari. Metode yang digunakan untuk menganalisis alat pengumpul data (kuesioner) adalah melakukan uji validitas (kesahihan) dan reliabilitas (keandalan). Pengolahan data untuk tujuan pertama dan kedua yaitu untuk mengetahui tingkat motivasi petani dan kualitas pelayanan penyuluhan pertanian adalah dengan menggunakan perhitungan skoring. Untuk skor penilaian motivasi intrinsik disajikan pada Tabel 1, skor tingkat motivasi petani menurut interval kelas pada Tabel 2, dan skor kualitas pelayanan penyuluhan pertanian pada Tabel 3. Sedangkan kategori tingkat motivasi petani dan tingkat kualitas pelayanan penyuluhan pertanian disajikan pada Tabel 4 dan 5. Parameter kualitas pelayanan penyuluh pertanian pada Tabel 6. Tujuan ketiga yaitu menganalisis hubungan antara motivasi petani dan kualitas pelayanan penyuluhan di Kecamatan Krayan dianalisis dengan menggunakan korelasi. Korelasi yang digunakan adalah korelasi Spearman Rank $(\rho)$. Kriteria Pengukuran koefisien korelasi Spearman Rank pada Tabel 7. Rumus dasar yang digunakan adalah sebagai berikut (Sugiyono, 2013) :

$$
\rho=1-\frac{6 \sum b i^{2}}{n\left(n^{2}-1\right)}
$$

Dimana $\rho=$ koefisien korelasi Spearman Rank

$$
\begin{aligned}
& \mathrm{n}=\text { responden } \\
& \mathrm{b}=\text { selisih } \mathrm{x} \text { dan } \mathrm{y}
\end{aligned}
$$

\section{HASIL DAN PEMBAHASAN \\ Penyuluhan Pertanian di Kecamatan Krayan}

Penyuluhan pertanian di Kecamatan Krayan dilakukan oleh penyuluh pertanian yang berada di BPP (Balai Penyuluhan Pertanian) Kecamatan Krayan. Balai Penyuluhan Pertanian Krayan yang mencakup lima kecamatan binaan yakni Kecamatan Krayan, Kecamatan Krayan Timur, Kecamatan Krayan Barat, Kecamatan Krayan Tengah dan Kecamatan Krayan Selatan.

Kegiatan penyuluhan dilaksanakan 2 sampai 4 kali dalam sebulan dikarenakan lokasi binaan memiliki topografi yang curam serta jarak antara daerah yang satu dengan lainnya letaknya berjauhan. Selain itu moda transportasi terbatas hanya di daerah tertentu saja. Masyarakat di Kecamatan Krayan sangat bergantung dari hasil pertanian sebagai mata pencaharian pokok, sehingga peran penyuluh dalam membimbing, mendampingi dan memfasilitasi petani selama berusaha tani sangat dibutuhkan. Salah satu faktor penentu dalam pembangunan pertanian adalah adanya kelembagaan penyuluhan pertanian dan aktifitasnya. Apabila kelembagaan penyuluhan pertanian yang ada semakin kuat, dinamis, tangguh dan cepat tanggap terhadap perubahaan dan kebutuhan petani, maka segala pembangunan di bidang pertanian akan cepat teradopsi oleh petani.

\section{Kearifan Lokal Pertanian Organik di Krayan}

Kecamatan Krayan memiliki produk unggulan yang sangat terkenal yaitu padi Adan. Padi adan merupakan padi yang berasal dari sistem pertanian organik. Produksi perhektare sekitar 3 ton gabah kering giling (GKG). Satu kepala keluarga (KK) mampu menghasilkan padi $1-4$ ton GKG permusim tanam. Masyarakat Krayan melakukan bercocok tanam hanya setahun 
sekali dan sistem pertaniannya murni organik.

Daerah persawahan penduduk relatif subur karena cekungan dari bukit dan gunung menyebabkan unsur hara terkumpul disebabkan proses leaching (etraksi padat cair). Sawah hijau terhampar pada 27 lokasi di 89 desa. Luas tanam padi berkisar \pm 3467 hektar. Jenis padi adan yang ditanam petani merupakan padi varietas lokal dengan 3 jenis yaitu adan putih,adan merah dan adan hitam. Padi adan ditanam petani tidak lepas dengan adanya kerbau yang banyak dipelihara petani. Disini terjadi simbiosis mutualisme antara tanaman padi dan kerbau. Kerbau mendapat makanan dari limbah jerami padi dan kotoran ternak kerbau menjadi pupuk organik bagi tanaman, sehingga padi mendapatkan unsur hara yang cukup dari tanah.

Pola tanamnya dimulai sejak dilakukan persiapan penebasan lahan sejak Maret hingga Mei. Lahan dibiarkan hingga Juni. Setelah panen kerbau digembala di lahan sawah dan berakhir pada saat tanam. Pada Juli hingga September dimulai penanaman padi, panen dilakukan Bulan Desember hingga Februari. Kerbau berfungsi untuk membantu mengembalikan unsur hara secara alami sekaligus memperbaiki struktur tanah, disamping itu juga kerbau dimanfaatkan untuk membantu petani sebagai alat angkutan, seperti hasil sawah dan hutan.

\section{Karakteristik Responden}

Karakteristik responden adalah sebagai berikut :

\section{Usia Responden}

Usia responden bervariasi, usia menunjukkan kemampuan secara fsik dan psikologis bagaimana petani bekerja serta berpikir untuk mengambil keputusan dalam berusahatani.

Sebagian besar responden berusia $43-55$ tahun $(55 \%)$. Rata-rata petani berusia produktif. Usia sangat berpengaruh pada petani ketika mendapatkan penyuluhan pertanian. Rata-rata usia produktif akan lebih mudah menyerap materi penyuluhan dan mengadopsi inovasi baru yang diberikan penyuluh. Menurut Simatupang (2017) secara phisikologis, tingkat adopsi kelompok usia tua lebih rendah daripada kelompok usia muda,tingkat kejenuhan dan stress kelompok usia tua lebih tinggi dari kelompok usia muda.

\section{Luas Lahan}

Petani rata-rata memiliki sekitar 3-4 ha sawah $(65 \%)$, biasanya sawah mereka kelola sendiri bersama keluarga. Semakin luas lahan yang dimiliki petani maka usahatani yang dilakukan semakin efisien. Produktivitas lahan sawah milik petani sekitar 2 - 3 ton GKG per hektar. Sekitar tahun 2016, petani telah dikenalkan sistem tanam yang memperhatikan jarak tanam yaitu sistem jarwo (jajar legowo). Petani yang telah mengadopsi jajar legowo, dapat memperoleh hasil panen $4-6$ ton /ha. Hal ini berarti dengan sistem jarwo dapat meningkatkan produktivitas. Mardikanto (2009) dalam Dewi (2016) menyatakan bahwa semakin luas lahan usahatani biasanya akan memiliki kemampuan ekonomi yang lebih baik.

Tabel 1. Luas Lahan

\begin{tabular}{|c|c|c|c|}
\hline No & Luas Lahan (ha) & Jumlah (Orang) & Persentase (\%) \\
\hline 1 & $1-2$ & 12 & 30 \\
\hline 2 & $3-4$ & 26 & 65 \\
\hline 3 & $5-7$ & 2 & 5 \\
\hline & Jumlah & $\mathbf{4 0}$ & $\mathbf{1 0 0}$ \\
\hline
\end{tabular}

Menurut Suprapto (2010) dari kondisi kepemilikan luas lahan yang bervariasi, berdampak pada pengelolaan usahatani yang juga bervariasi. Variasi pengelolaan lahan terutama pada penggunaan input bibit, pupuk dan obat-obatan. Dimana pada kepemilikan lahan yang sempit oleh petani, cenderung melakukan aplikasi sarana produksi pertanian per hektar rata-rata lebih tinggi. Disamping itu perawatan juga lebih intensif, misalnya berupa kegiatan penyiangan, aplikasi pupuk, pestisida organik, pengairan dan lainnya. 


\section{Pengalaman Berusahatani}

Pengalaman berusahatani rata-rata 11-17 tahun $(27,5 \%)$, pengalaman berusahatani memberikan pembelajaran bagi petani untuk pengambilan keputusan-keputusan selama berusaha tani.

Tabel 2. Pengalaman Berusahatani

\begin{tabular}{|c|c|c|c|}
\hline No & Pengalaman (Tahun) & Jumlah (Orang) & Persentase (\%) \\
\hline 1 & $4-10$ & 18 & 45 \\
\hline 2 & $11-17$ & 11 & 27,5 \\
\hline 3 & $18-24$ & 6 & 15 \\
\hline 4 & $25-31$ & 2 & 5 \\
\hline 5 & $32-40$ & 3 & 7,5 \\
\hline & Jumlah & $\mathbf{4 0}$ & $\mathbf{1 0 0}$ \\
\hline
\end{tabular}

Pengalaman berusahatani sangat berpengaruh pada perilaku petani, semakin petani memiliki pengalaman yang lama maka petani dapat memperkecil resiko kegagalan panennya dengan belajar dari pengalaman. Pengalaman petani dapat juga disesuaikan dengan inovasi baru yang diberikan penyuluh sehingga bisa saling bersinergi untuk menghasilkan metode yang lebih tepat dan efisien sehingga bisa meningkatkan produktivitas.

\section{Uji Validitas dan Reliabilitas Data}

Uji validitas dan reliabilitas digunakan untuk menguji pertanyaan dalam kuesioner apakah sudah terukur dan teruji keandalannya. Berikut hasil uji validitas dan reliabilitas.

Tabel 3. Uji Reliabilitas Variabel Motivasi

\begin{tabular}{|c|c|c|}
\hline Uji Reliabilitas & Nilai & Keterangan \\
\hline Cronbach's Alpha & 0,790 & Sangat Reliabel \\
\hline
\end{tabular}

Sumber : Data Primer diolah, 2018

Nilai Cronbach's Alpha pada uji reliabilitas diperoleh nilai sebesar 0,790 hal ini menunjukkan bahwa kuesioner yang digunakan untuk memperoleh data dari responden adalah sangat reliabel sehingga dapat dipakai sebagai alat pengumpulan data yang diperlukan dalam penelitian.

Tabel 4. Uji Validitas Data Variabel Motivasi

\begin{tabular}{|l|l|l|}
\hline \multicolumn{1}{|c|}{ Butir } & $\begin{array}{c}\text { Corrected Item } \\
\text { Total Correlation }\end{array}$ & Keterangan \\
\hline Butir 1 & 0,645 & Valid \\
\hline Butir 2 & 0,736 & Valid \\
\hline Butir 3 & 0,298 & Valid \\
\hline Butir 4 & 0,399 & Valid \\
\hline Butir 5 & 0,708 & Valid \\
\hline Butir 6 & 0,431 & Valid \\
\hline Butir 7 & 0,332 & Valid \\
\hline Butir 8 & 0,479 & Valid \\
\hline
\end{tabular}

Sumber : Data Primer diolah, 2018

Berdasarkan uji validitas maka diperoleh nilai korelasi untuk masing - masing butir pertanyaan. Nilai korelasi tabel untuk $\mathrm{N}=40$ adalah 0,2638 dengan signifikansi 5\% maka nilai $r$ hitung $>r$ tabel untuk semua butir
pertanyaan.Oleh karena itu setiap butir pertanyaan dinyatakan valid dan kuesioner bisa digunakan sebagai instrument untuk pengumpulan data responden. 
Tabel 5. Uji Reliabilitas Variabel Kualitas Pelayanan

\begin{tabular}{|c|c|c|}
\hline Uji Reliabilitas & Nilai & Keterangan \\
\hline Cronbach's Alpha & 0,908 & Sangat Reliabel \\
\hline
\end{tabular}

Tabel 6. Uji Validitas Data Variabel Kualitas Pelayanan

\begin{tabular}{|l|l|l|}
\hline $\begin{array}{l}\text { Butir } \\
\text { Pertanyaan }\end{array}$ & $\begin{array}{l}\text { Corrected Item } \\
\text { Total Correlation }\end{array}$ & Keterangan \\
\hline Butir 1 & 0,551 & Valid \\
\hline Butir 2 & 0,527 & Valid \\
\hline Butir 3 & 0,849 & Valid \\
\hline Butir 4 & 0,464 & Valid \\
\hline Butir 5 & 0,606 & Valid \\
\hline Butir 6 & 0,327 & Valid \\
\hline Butir 7 & 0,481 & Valid \\
\hline Butir 8 & 0,789 & Valid \\
\hline Butir 9 & 0,684 & Valid \\
\hline Butir 10 & 0,460 & Valid \\
\hline Butir 11 & 0,593 & Valid \\
\hline Butir 12 & 0,457 & Valid \\
\hline Butir 13 & 0,720 & Valid \\
\hline Butir 14 & 0,907 & Valid \\
\hline Butir 15 & 0,743 & Valid \\
\hline
\end{tabular}

Sumber : Data Primer diolah, 2018

Berdasarkan uji validitas maka diperoleh nilai korelasi untuk masing - masing butir pertanyaan. Nilai korelasi tabel untuk $\mathrm{N}=40$ adalah 0,2638 dengan signifikansi 5\% maka nilai $r$ hitung $>r$ tabel untuk semua butir pertanyaan.Oleh karena itu setiap butir pertanyaan dinyatakan valid dan kuesioner bisa digunakan sebagai instrument untuk pengumpulan data responden.

\section{Tingkat Motivasi Petani}

Tingkat motivasi petani terbagi dalam 2 yaitu motivasi intrinsik dan motivasi ektrinsik. Semakin tinggi motivasi petani maka tingkat partisipasi petani dalam penyuluhan akan semakin meningkat. Sehingga tujuan penyuluhan akan mudah tercapai. Motivasi intrinsik terbangun dari dalam diri petani yang meliputi keinginan meningkatkan prestasi,penghargaan, tanggungjawab dan keinginan untuk lebih maju. Motivasi ektrinsik berasal dari luar diri petani yang dipengaruhi oleh lingkungan sekitar meliputi : kompensasi, status sosial,supervise dan kompetisi. Hal ini sesuai dengan pendapat Hasibuan (2016) yang menyatakan tingkah laku seseorang dipengaruhi serta dirangsang oleh keinginan,kebutuhan,tujuan dan kepuasaanya. Tingkat motivasi petani mengikuti penyuluhan dapat dilihat pada tabel 16 berikut ini:

Tabel 7. Tingkat Motivasi Petani

\begin{tabular}{|c|c|c|c|c|}
\hline No & $\begin{array}{l}\text { Interval } \\
\text { Kelas }\end{array}$ & $\begin{array}{l}\text { Jumlah } \\
\text { (orang) }\end{array}$ & $\begin{array}{l}\text { Persentase } \\
(\%)\end{array}$ & Ket. \\
\hline 1. & $8-13$ & 0 & 0 & $\begin{array}{l}\text { Sangat } \\
\text { Rendah }\end{array}$ \\
\hline 2. & $14-19$ & 0 & 0 & Rendah \\
\hline 3. & $20-25$ & 0 & 0 & Cukup \\
\hline 4. & $26-32$ & 24 & 60 & Tinggi \\
\hline 5. & $33-40$ & 16 & 40 & $\begin{array}{l}\text { Sangat } \\
\text { Tinggi }\end{array}$ \\
\hline & Total & 40 & 100 & \\
\hline
\end{tabular}

Sumber : Data Primer diolah, 2018 
Berdasarkan tabel maka diperoleh hasil persentase motivasi petani masuk dalam kategori tinggi (60\%). Tingginya motivasi terlihat dari partisipasi petani dalam mengikuti penyuluhan maupun mengikuti pelatihan yang diadakan oleh Balai Penyuluhan Pertanian Kecamatan Krayan. Penyuluhan diberikan minimal sebulan sekali, dengan membahas permasalahan yang dihadapi petani kemudian didiskusikan bersama untuk memperoleh solusi bersama. Pelatihan yang pernah diberikan penyuluh misalnya pelatihan pembuatan pupuk organik, pelatihan pengendalian hama terpadu (PHT) dan pelatihan penanaman sistem jajar legowo. Hal ini sesuai dengan pendapat Menurut Mayasari (2015) setiap petani mempunyai motivasi yang berbeda sebagai pendorong dalam melakukan suatu kegiatan usahatani. Motivasi petani dalam mengembangkan pertanian di perkotaan dapat dilihat dari motivasi fisiologi (physiologial needs) yaitu kondisi yang mendorong petani untuk cenderung memenuhi kebutuhan ekonomi dan motivasi sosiologi. Motif merupakan sumber dari tindakan yang bertujuan, motif menjadi aktif jika digerakkan oleh berbagai faktor yang kemudian menjadi tujuan yang hendak dicapai baik secara internal maupun eksternal. Salah satu motivasi yang menjadi dorongan petani untuk meningkatkan usahatani adalah pendapatan (Suprayitno ,2012 dalam Dewi ,2016).

\section{Kualitas Pelayanan Penyuluhan}

Atribut kualitas pelayanan penyuluhan yang digunakan dalam penelitian ini adalah : Aspek fisik (tangible), keandalan (Reliability), daya tanggap (responsiviness), jaminan (assurance) dan empati (Empathy). Penyuluh Pertanian diarahkan untuk melaksanakan tugas pendampingan dan konsultasi bagi pelaku utama dan pelaku usaha dalam mengembangkan usaha agribisnisnya, sehingga adopsi teknologi tepat guna dapat berjalan dengan baik dan pada gilirannya meningkatkan pemberdayaan pelaku utama, produksi, produktivitas, pendapatan dan kesejahteraan petani beserta keluarganya. (Permentan, 2013).

\section{Aspek Fisik (tangible)}

Aspek fisik meliputi sarana dan prasarana yang digunakan selama proses penyuluhan, misalnya bangunan (Balai Penyuluhan Pertanian), media penyuluhan serta ketersediaan penyuluh pertanian yang memberikan penyuluhan. Adapun persepsi responden terhadap kualitas pelayanan penyuluhan dari aspek fisik adalah sebagai berikut :

Tabel 7. Aspek Fisik (tangible)

\begin{tabular}{llccc}
\hline \hline No & Interval & Frekuensi (orang) & Persentase & Kualitas Pelayanan \\
\hline 1. & $3-6$ & 0 & 0 & Buruk \\
2. & $7-10$ & 3 & $7,5 \%$ & Cukup \\
3. & $11-15$ & 37 & $92,5 \%$ & Baik \\
\hline & Jumlah & 40 & $100 \%$ & \\
\hline
\end{tabular}

Berdasarkan tabel terlihat bahwa 92,5\% responden memiliki persepsi bahwa kualitas pelayanan penyuluhan dalam kategori tinggi. Hal ini menunjukkan bahwa petani merasa puas terhadap pelayanan penyuluhan yang diberikan oleh BPP Kecamatan Krayan. Hal ini dapat terlihat bahwa di Kecamatan Krayan telah ada Balai Penyuluhan Pertanian sebagai tempat berkumpulnya penyuluh dan sebagai tempat berdiskusi antara penyuluh dan petani. Media penyuluhan yang digunakan masih sederhana, di BPP belum tersedia LCD untuk bisa digunakan dalam penyuluhan namun penyuluhan tetap dilakukan dengan media yang ada dan petani telah merasa puas dengan materi yang disampaikan penyuluh.

Kualitas pelayanan penyuluhan sangat berpengaruh terhadap kepuasan petani hal ini sesuai dengan pendapat Simatupang (2017) Kualitas layanan penyuluhan yang seharusnya 
menjadi penilaian mencakup ketepatan pelayanan penyuluhan maupun penampilan penyuluh. Tingkat kepuasan sebagian besar petani terhadap layanan penyuluh tergolong tinggi. Walaupun selama ini pelayanan penyuluhan dirasakan belum memadai dalam membantu kebutuhan petani, terutama ketika petani menghadapi suatu jenis masalah yang benar-benar mengharapkan bantuan penyuluhan seringkali petani sulit untuk mencari bantuan, termasuk bantuan penyuluhan. Keadaan sulit ini lebih diperparah ketika petani tidak memiliki kemampuan untuk mengambil keputusan secara cepat dan tepat sehingga yang dilakukan petani biasanya hanya pasrah pada keadaan.

\section{Reliability (Kehandalan)}

Aspek reliability merupakan aspek kehandalan penyuluh dalam melakukan kegiatan penyuluhan. Meliputi kemampuan penyuluh memberikan pelayanan yang dijanjikan dengan segera, akurat dan memuaskan. Adapun hasil tabulasi persepsi petani terhadap aspek reliability adalah sebagai berikut:

Tabel 8. Aspek Kehandalan (Reliability)

\begin{tabular}{llccl}
\hline No & Interval Kelas & Frekuensi (Orang) & Persentase & Kualitas Pelayanan \\
\hline 1. & $3-6$ & 0 & 0 & Buruk \\
2. & $7-10$ & 2 & $5 \%$ & Cukup \\
3. & $11-15$ & 38 & $95 \%$ & Baik
\end{tabular}

\begin{tabular}{c}
\hline Jumlah \\
Sumber : Data Primer diolah, 2018
\end{tabular}

Berdasarkan tabel 18 maka 95\% petani merasa kualitas pelayanan penyuluhan dalam aspek kehandalan termasuk dalam kategori baik. Hal ini didukung oleh kualitas sumber daya manusia terutama penyuluh. Rata-rata penyuluh telah menempuh pendidikan S1 sebanyak $80 \%$, selain itu penyuluh selalu meningkatkan kompetensi diri dengan mengikuti pelatihan - pelatihan baik yang diadakan oleh Dinas Pertanian Kabupaten Nunukan maupun mengikuti pelatihan di Tingkat nasional. Semakin meningkat kompetensi penyuluh baik melalui pendidikan formal maupun non formal maka pelayanan penyuluhan yang diberikan kepada petani semakin meningkat. Hal ini sesuai dengan pendapat Kepuasan petani terhadap kegiatan penyuluhan pertanian merupakan syarat penting agar kegiatan penyuluhan pertanian berjalan secara efektif. Kepuasan pada petani akan membuat petani secara sadar dan berkemauan tinggi untuk melakukan perubahan dalam berusahatani yang memungkinkan mereka mencapai keberhasilan (Berkat, 2015).
Kualitas materi penyuluhan yang diberikan kepada petani merupakan salahsatu aspek yang mempengaruhi. Materi disesuaikan dengan kebutuhan dan permasalahan yang dihadapi oleh petani untuk dicarikan solusi bersama. Penyuluh juga mendampingi petani dalam penyusunan Rencana Definitive Kebutuhan kelompok (RDKK). Hal ini sesuai pendapat Mardikanto ( 2009) yang menyatakan bahwa materi penyuluhan yang disampaikan oleh seorang penyuluh harus selalu mengacu kepada kebutuhan yang telah dirasakan oleh masyarakat penerima manfaatnya. Tetapi di dalam prakteknya seringkali penyuluh menghadapi kesulitan untuk memilih dan menyajikan materi yang benar-benar dibutuhkan oleh masyarakat penerima manfaatnya. Hal ini bisa disebabkan karena keragaman penerima manfaat yang dihadapi atau keragaman materi yang harus disampaikan pada saat yang sama. Metode penyuluhan yang digunakan penyuluh pada petani di BPP Krayan menggunakan metode ceramah dan diskusi disesuaikan dengan waktu luang petani. Sesuai pendapat Mardikanto 
dalam Farida (2012), pemilihan metode pendidikan orang dewasa (termasuk penyuluhan) harus selalu mempertimbangkan: (1) waktu penyelenggaraan yang tidak terlalu mengganggu kegiatan/pekerjaan pokoknya, (2) waktu penyelenggaraan sesingkat-singkatnya, dan (3) lebih banyak menggunakan alat peraga.

\section{Daya tanggap (Responsiviness)}

Responsiviness merupakan daya tanggap atau kemampuan penyuluh untuk memberikan respon terhadap permasalahan yang dihadapi petani. Selain itu juga dilihat dari ketepatan penyuluh dalam memberikan solusi pada petani dan kesediaan penyuluh dalam membantu petani.Kualitas penyuluhan dilihat dari aspek responsiviness dapat dilihat dari tabel berikut :

Tabel 9. Aspek Daya Tanggap (Responsiviness)

\begin{tabular}{llccc}
\hline \hline No & Interval Kelas & Frekuensi (Orang) & Persentase & Kualitas Pelayanan \\
\hline 1. & $3-6$ & 0 & 0 & Buruk \\
2. & $7-10$ & 1 & $2,5 \%$ & Cukup \\
3. & $11-15$ & 39 & $97,5 \%$ & Baik \\
\hline \multicolumn{7}{l}{ Jumlah } & 40 & $100 \%$ & \\
\hline
\end{tabular}

Sumber : Data Primer diolah, 2018

Berdasarkan tabel 19 terlihat bahwa 97,50\% responden menyatakan daya tanggap penyuluh termasuk dalam kategori baik dalam membantu petani menyelesaikan masalah yang dihadapi di usahataninya. Hal ini sangat didukung oleh peran penyuluh sebagai fasilitator, yang memberikan kemudahan-kemudahan pada petani serta berperan sebagai konsultan, dimana petani dapat berkonsultasi dengan mudah kepada penyuluh. Menurut Saputri (2016) peningkatan peran penyuluh sebagai fasilitator ini sangat membantu petani dalam meningkatkan perkembangan kelompok tani. Perkembagan kelompok harus didasari dengan peningkatan kapasitas petani. Peningkatan kapasitas petani bisa dengan cara meningkatkan pengetahuan, ketrampilan dan sikap petani dalam kelompok dan dalam berusahatani. Peningkatan pengetahuan, ketrampilan dan sikap ini sangat membantu petani, hal tersebut diharapkan dengan peningkatan kapasitas diri petani, petani akan lebih termotivasi dalam melakukan peningkatan perkembangan kelompok tani.

Meskipun secara geografis wilayah Kecamatan Krayan berupa dataran tinggi dan masih terdapat hutan dengan jalan yang susah dilewati apabila hujan, tidak mengurangi semangat para PPL untuk selalu mendampingi petani.

\section{Jaminan( Assurance)}

Jaminan Kualitas penyuluhan dapat dilihat dari kesiapan penyuluh dalam membuat perencanaan penyuluhan, pelaksanaan penyuluhan dan evaluasi penyuluhan. Puspadi dalam Tahitu (2013) menjelaskan bahwa pada hakekatnya kualitas dari kegiatan penyuluhan pertanian merupakan fungsi kualitas sumberdaya manusia penyuluh pertanian. Kualitas kegiatan penyuluhan pertanian diukur dengan lima indikator, yaitu: (1) materi penyuluhan pertanian, (2) domain yang disentuh dalam melaksanakan rangkaian kegiatan penyuluhan pertanian, (3) memfasilitasi keputusan-keputusan dari petani, (4) keberpihakan kepada petani, dan (5) intensitas kunjungan penyuluh pertanian ke wilayah binaannya. Kualitas pelayanan penyuluhan diharapkan dapat menimbulkan kepuasan bagi petani yang selanjutnya akan bermanfaat dalam upaya ikut meningkatkan kapasitasnya.

Persiapan penyuluhan terlihat dari penyuluh telah menyusun programa penyuluhan pertanian,membuat data potensi wilayah dan mendampingi petani dalam penyusunan RDKK. Dalam pelaksanaan penyuluhan,penyuluh telah menerapkan metode penyuluhan pertanian yang disesuaikan dengan karakteristik petani dan kondisi wilayah. Penyuluh juga telah meningkatkan kapasitas petani,dengan memberikan pelatihan-pelatihan kepada petani. Pelatihan yang diberikan misalnya pelatihan pembuatan pupuk organik,pelatihan 
pengendalian hama terpadu dan pelatihan pengelolaan tanaman terpadu. Semua aktivitas penyuluhan yang dilakukan di evaluasi penyuluh dan dibuatkan laporan pelaksanaan penyuluhan pertanian, agar tiap tahun dapat di evaluasi sejauh mana keberhasilan programa penyuluhan yang dilaksanakan. Hal ini sesuai dengan pendapat Farida (2012) bahwa Persepsi petani terhadap kompetensi andragogik PPL adalah mengenai kemampuan PPL dalam memahami petani dan mengembangkan kebutuhan belajar untuk berubah.

Tabel 10. Jaminan( Assurance)

\begin{tabular}{llccc}
\hline \hline No & Interval Kelas & Frekuensi (Orang) & Persentase & Kualitas Pelayanan \\
\hline 1. & $3-6$ & 0 & 0 & Buruk \\
2. & $7-10$ & 3 & $7,5 \%$ & Cukup \\
3. & $11-15$ & 37 & $92,5 \%$ & Baik \\
\hline \multicolumn{7}{l}{ Jumlah } & 40 & $100 \%$ & \\
\hline
\end{tabular}

Sumber : Data Primer diolah, 2018

Berdasarkan tabel , 92,5\% responden menyatakan bahwa kualitas pelayanan penyuluhan adalah baik. Jaminan kualitas pelayanan yang baik akan menjadi motivasi para penyuluh untuk selalu meningkatkan mutu layanan pada petani yang berhubungan dengan peran penyuluh sehingga petani merasa puas dengan penyuluhan yang diberikan. Penyuluhan sangat dibutuhkan bagi petani terutama bagi petani di perbatasan. Dengan sarana prasarana yang terbatas,semua kegiatan penyuluhan dapat dilaksanakan, dan petani mendapat manfaat dari kegiatan penyuluhan tersebut.Kemampuan penyuluh dalam memahami kebutuhan petani dan memberikan layanan informasi dan pengetahuan baru bagi petani akan sangat mendukung kualitas pelayanan penyuluhan yang diberikan oleh penyuluh.

\section{Empati ( Emphaty )}

Seorang penyuluh harus memiliki rasa empati kepada petani. Rasa Empati yang dimiliki penyuluh dapat mempererat hubungan antara penyuluh dan petani sasaran. Empati dapat diukur dari kemampuan penyuluh dalam mendengarkan keluhan petani, penyuluh mengetahui kebutuhan petani dan penyuluh mampu berkomunikasi efektif dengan petani. Adapun hasil kualitas penyuluhan dari aspek empati dapat dilihat pada tabel berikut :

Tabel 11. Empati (Emphaty)

\begin{tabular}{|c|c|c|c|c|}
\hline No & Interval Kelas & Frekuensi (Orang) & Persentase & Kualitas Pelayanan \\
\hline 1. & $3-6$ & 0 & 0 & Buruk \\
\hline 2. & $7-10$ & 2 & $5 \%$ & Cukup \\
\hline \multirow[t]{2}{*}{3.} & $11-15$ & 38 & $95 \%$ & Baik \\
\hline & Jumlah & 40 & $100 \%$ & \\
\hline
\end{tabular}

Sumber : Data Primer diolah, 2018

Berdasarkan hasil tabel $95 \%$ responden menyatakan aspek empati penyuluh dalam kualitas penyuluhan termasuk dalam kategori baik. Hal ini terlihat dari hubungan yang harmonis antara penyuluh dan petani. Komunikasi telah terjalin efektif, sehingga informasi dan materi penyuluhan tersampaikan dengan baik. Hal ini sesuai dengan pendapat
Wijayanti (2015) yang menyatakan dimensi kelima kualitas jasa untuk mengukur tingkat kepuasan petani terhadap kinerja Penyuluh Pertanian Lapangan (PPL) di Kabupaten Kutai Timur adalah emphathy (empati) yang dilihat dari mudahnya PPL ditemui atau dihubungi, keadilan dalam memberikan pelayanan dan ketepatan waktu dalam memberikan 
penyuluhan atau pelayanan. Dari 4 sub indikator yang diajukan, petani menilai bahwa PPL mudah untuk ditemui atau dihubungi oleh petani mendapatkan skor realita tertinggi yaitu 4,23 (sangat baik) sedangkan harapan petani sebesar 4,47 (sangat diharapkan), sehingga masih terjadi gap sebesar 0,23. Hal ini menunjukan PPL mudah untuk ditemui atau dihubungi oleh petani sudah sangat baik hanya saja masih perlu ditingkatkan mengingat masih ada gap antara realita dan harapan. Secara keseluruhan Kualitas Pelayanan Penyuluhan dapat dilihat pada tabel berikut :

Tabel 12. Tingkat Kualitas Pelayanan Penyuluhan

\begin{tabular}{llccl}
\hline \hline No & Interval Kelas & Frekuensi & Persentase $(\%)$ & Tingkat Kualitas Pelayanan \\
\hline 1. & $15-26$ & 0 & 0 & Sangat Buruk \\
\hline 2. & $27-38$ & 0 & 0 & Buruk \\
3. & $39-50$ & 2 & 5 & Cukup \\
4. & $51-62$ & 17 & 42,5 & Baik \\
5. & $63-75$ & 21 & 52,5 & Sangat Baik \\
\hline
\end{tabular}

Sumber : Data Primer diolah, 2018

Berdasarkan tabel 22, responden menyatakan $5 \%$ kualitas pelayanan dalam kategori cukup, 42,5\% dalam kategori baik dan $52,5 \%$ responden menyatakan kualitas pelayanan sangat baik. Kualitas pelayan penyuluhan dapat dilihat dari 5 dimensi (tangible, resposiviness, reliability, assurance dan emphaty). Penyuluh dituntut mampu memberikan pelayanan yang prima terhadap petani agar tujuan penyuluhan bisa tercapai. Tujuan penyuluhan adalah mengubah perilaku petani (pengetahuan, sikap dan keterampilan) sehingga mereka mampu bertani berusaha tani dengan baik (better farming), bertani lebih menguntungkan (better business) dan petani lebih hidup sejahtera (better living). Semakin baik kualitas pelayanan yang diberikan maka citra dan reputasi dari penyuluhan akan semakin baik. Hal ini sesuai dengan pendapat Kotler (2000) dalam Berkat (2015) bahwa kepuasan pelanggan merupakan kepuasan terhadap sesuatu pelayanan serta bagaimana pelayanan itu dapat memenuhi harapan pelanggan secara baik. Dalam kontek penyuluhan pertanian berarti kepuasan petani terjadi apabila mereka menerima jasa penyuluhan pertanian sesuai dengan yang mereka pikirkan atau harapkan sebelumnya.

\section{Hubungan Antara Motivasi Petani dan Kualitas Pelayanan Penyuluhan}

Motivasi petani merupakan motivasi petani untuk perpartisipasi aktif dalam mengikuti penyuluhan. Motivasi dapat berasal dari faktor intrinsik (dalam diri) dan ekstrinsik ( pengaruh lingkungan). Motivasi petani juga berhubungan dengan kualitas pelayanan penyuluhan. Motivasi petani perlu didukung oleh mutu layanan penyuluhan yang baik,agar petani merasakan manfaat dan merasa puas dengan mengikuti penyuluhan yang diadakan oleh BPP Kecamatan Krayan. Berikut hasil analisis korelasi antara tingkat motivasi dan tingkat kualitas pelayanan penyuluhan dengan menggunakan bantuan SPSS :

Tabel 13. Hasil Analisis Korelasi Tingkat Motivasi Petani dan Tingkat Kualitas Pelayanan Penyuluhan

\begin{tabular}{|l|l|l|l|}
\hline No & \multicolumn{1}{|c|}{ Uraian Korelasi Spearman Rank } & \multicolumn{1}{c|}{ Nilai } & \multicolumn{1}{c|}{ Keterangan } \\
\hline 1. & Koefisien Korelasi & 0,566 & Sedang \\
\hline 2. & Signifikansi & 0,000 & Signifikan \\
\hline
\end{tabular}

Sumber : Data Primer diolah, 2018

Berdasarkan uji korelasi maka hubungan antara tingkat motivasi dan tingkat kualitas pelayanan penyuluhan dalam kategori hubungan yang sedang / cukup kuat dan 
signifikan dengan hubungan yang positif atau searah. Hal ini menunjukan bahwa semakin tinggi motivasi petani maka akan semakin baik kualitas pelayanan penyuluhan yang diberikan. Penyuluhan akan terjalin secara efektif apabila didukung partisipasi aktif dari petani. Sesuai dengan pengertian penyuluhan menurut Undang-Undang No 16 Tahun 2006 Tentang Sistem Penyuluhan Pertanian, Perikanan dan Kehutanan (UU SP3K) penyuluhan adalah proses pembelajaran bagi pelaku utama serta pelaku usaha agar mereka mau dan mampu menolong dan mengorganisasikan dirinya dalam mengakses informasi pasar, teknologi, permodalan, dan sumberdaya lainnya, sebagai upaya untuk meningkatkan produktivitas, efisiensi usaha, pendapatan, dan kesejahteraannya, serta meningkatkan kesadaran dalam pelestarian fungsi lingkungan hidup. Petani yang telah termotivasi untuk berpartisipasi aktif dalam penyuluhan tentu perlu didukung dengan layanan penyuluhan yang didapatkannya yang meliputi kelima dimensi aspek layanan tersebut. Peran pemerintah sebagai penentu kebijakan penyuluhan pertanian juga sangat berpengaruh terhadap pelayanan yang diberikan oleh lembaga penyuluhan melalui dinas terkait Proses penyuluhan antara penyuluh dan petani merupakan penghubung yang bersifat dua arah antara pengetahuan yang dibutuhkan petani dengan pengalaman baru yang terjadi dipihak para ahli dan kondisi nyata yang dialami petani. Sehingga penyuluhan pertanian akan dapat terselenggara dengan produktif, efektif dan efisien apabila didukung oleh para penyuluh pertanian yang menguasai materi, metode, teknik, organisasi, instrumen-instrumen dan manajemen penyuluhan pertanian dengan baik.

\section{KESIMPULAN}

1. Tingkat motivasi petani mengikuti penyuluhan pertanian $60 \%$ dalam kategori tinggi dan $40 \%$ motivasi petani sangat tinggi untuk mengikuti penyuluhan.

2. Kualitas pelayanan penyuluhan pertanian dilihat dari lima dimensi yaitu fisik (tangible), kehandalan (reliability), daya tanggap (responsiviness), jaminan (assurance) dan empati (emphaty). Secara keseluruhan responden menyatakan $5 \%$ kualitas pelayanan cukup baik, $42,5 \%$ baik dan $52,5 \%$ kualitas pelayanan penyuluhan dalam kategori sangat baik.

3. Hubungan antara tingkat motivasi dan kualitas pelayanan penyuluhan dianalisis menggunakan korelasi spearman rank memiliki koefisien 0,566 (korelasi sedang) dengan signifikan 0,000.

\section{UCAPAN TERIMA KASIH}

Penulis mengucap terima kasih atas dukungan sehingga laporan penelitian dosen pemula dapat terselesaikan :

1. Tuhan Yang Maha Esa atas rahmat dan karuniaNYA.

2. Lembaga Penelitian dan Pengabdian Masyarakat (LP2M) Universitas Borneo Tarakan.

3. Balai Penyuluhan Pertanian (BPP) Kecamatan Krayan Kabupaten Nunukan.

4. Dekan Fakultas Pertanian Universitas Borneo Tarakan.

5. Semua pihak yang telah membantu sehingga terselesaikannya laporan akhir ini.

\section{DAFTAR PUSTAKA}

Arikunto, S.2008. Prosedur Penelitian. Penerbit Rineka Cipta. Jakarta.

Abubakar, 2010. Kualitas Pelayanan Penyuluh Pertanian dan Kepuasaan Petani Dalam Penanganan dan Pengolahan Hasil Ubi Jalar. Jurnal Penyuluhan Pertanian Vol.5 (1).

Alif,Muhammad, 2017. Partisipasi Petani Dalam Komunikasi Penyuluhan. Journal Of Communication Studies Vol 2 (2).

Asih, Dewi.2009. Analisis Karakteristik dan Tingkat Pendapatan Usahatani Bawang Merah di Sulawesi Tengah.Jurnal Agroland Volume 16 (1): 53-59.

Balai Penyuluhan Pertanian, 2018. Programa Penyuluhan Pertanian, Kecamatan Krayan.

Berkat dan Sunaryati, 2015. Analisis Kepuasan Petani Terhadap Kegiatan Penyuluhan Pertanian di Kelurahan Kalampangan Kota 
Palangka Raya Kalimantan Tengah.Jurnal Agribisnis Vol 9 (1) : 1 - 10.

Dewi,Utami dan Ihsaniyati, 2016. Motivasi Petani Berusahatani Padi.Jurnal Agrista Vol 4 (3) : $104-114$.

Farida, Ida. 2012.Persepsi Petani Terhadap Kompetensi Penyuluh Pertanian Lapang di Kecamatan Pontang Kabupaten Serang Provinsi Banten, Tesis. Sekolah Pasca Sarjana, IPB.Bogor.

Harmoko, 2017. Tingkat Motivasi Petani Dalam Beternak Sapi di Kecamatan Sambas Kabupaten Sambas, JSEP Vol 10 (1).
Hidayanti, Nurmia,2015. Motivasi Petani Kakao Begabung Dalam Kelompok Tani di Kelurahan Kapalo Koto Kecamatan Payakumbuh Selatan. Jurnal Faperta No 2 (2).

Marsaulina, Mindo,2014. Persepsi Petani Padi Terhadap Kegiatan Penyuluhan Pertanian di Desa Sukarami Kelurahan Taba Penanjung Kabupaten Bengkulu Tengah . Jurnal Agritepa Vol 1(1). 